\title{
ASPEK-ASPEK GEODETIK DALAM HUKUM LAUT
}

\author{
Joko Hartadi \\ Program Studi Teknik Geologi, Fakultas Teknologi Mineral, \\ Universitas Pembangunan Nasional "Veteran" Yogyakarta \\ email: jokohartadi@upnyk.ac.id
}

\begin{abstract}
Abstrak. Pada tahun 1982 Konvensi PBB Tentang Hukum Laut III mengakui bahwa lebar laut teritorial Negara kepulauan adalah 12 mil dengan lebar Zona Ekonomi Eksklusif (ZEE) selebar 200 mil. Menurut konvensi tersebut setiap Negara harus melaporkan koordinat batas-batas, baik batas laut teritorial maupun batas ZEE. Masalah yang dihadapi Indonesia adalah koordinat batas yang dilaporkan bukan merupakan mengukuran langsung di lapangan tetapi diperoleh dari perhitungan di peta. Di masa depan koordinat yang dilaporkan harus diperoleh melalui pengukuran langsung di lapangan.
\end{abstract}

Kata Kunci: Hukum Laut III, ZEE, koordinat batas.

Abstract. In 1982 UNCLOS III (United Nations Convention on the Law of the Sea III) admitted that Archipelago State's sea width is 12 miles and EEZ (Exclusive Economic Zone) width is 200 miles. Based on UNCLOS III, each state has to report its boundaries coordinate, both territorial sea and EEZ. For Indonesia, the problem is the reported boundaries are not based on research and measurement in the sea, instead on map calculation. It is such a lesson learned that Indonesian people have to do some research and measurement in the sea directly next time.

Keywords: UNCLOS III, EEZ, boundaries coordinate.

\section{PENDAHULUAN}

\section{Latar Belakang}

Sejarah Hukum Laut di Indonesia dimulai sejak Ordonansi No. 525 Tahun 1939, yang menyatakan bahwa batas teritorial negara selebar 3 mil laut. Atas pertimbangan situasi dan keamanan, pada 13 Desember 1957 Pemerintah Republik Indonesia mengeluarkan deklarasi yang dikenal sebagai deklarasi Juanda, mengenai wilayah perairan Indonesia. Dalam deklarasi tersebut batas kedaulatan negara adalah 12 mil laut diukur dari garis-garis yang menghubungkan titik-titik terluar pada pulau-pulau Negara Republik Indonesia.

Deklarasi Juanda pada tahun 1960 dikuatkan dengan undang-undang, yaitu melalui UndangUndang No. 4/Prp Tahun 1960. Undang-undang tersebut terdiri atas empat pasal yang merubah cara penetapan laut wilayah Indonesia dari 3 mil laut diukur dari garis pasang surut atau garis air rendah (low water line) menjadi 12 mil laut diukur dari garis pangkal lurus yang ditarik dari ujung ke ujung (Kusumaatmadja, 1978).
Secara internasional dalam UNCLOS III (United Nations Convention on the Law of the Sea III) pada tahun 1982 mengakui adanya negara kepulauan dengan laut teritorial selebar 12 mil laut. UNCLOS III juga mengakui adanya Zona Ekonomi Eksklusif (ZEE) selebar 200 mil laut dimana setiap negara mempunyai hak berdaulat untuk melakukan kegiatan pemanfaatan sumber daya hayati dan nonhayati dalam zona tersebut.

Sesuai UNCLOS III, pemerintah Indonesia menindaklanjuti dengan meratifikasinya melalui Undang-Undang No. 17 Tahun 1985. Selanjutnya pada tahun 1996 pemerintah mengeluarkan Undang-Undang No. 6 Tahun 1996 Tentang Perairan Indonesia, yang mencabut Undang-Undang No. 4/Prp Tahun 1960.

Berdasarkan UNCLOS III, data fisik Wilayah Republik Indonesia (termasuk wilayah laut) menjadi (Rais, 2001):

\footnotetext{
Perairan Nusantara : 2,8 juta $\mathrm{km}^{2}$ - perairan kepulauan,

Laut Teritorial : 0,3 juta $\mathrm{km}^{2}$,
} 


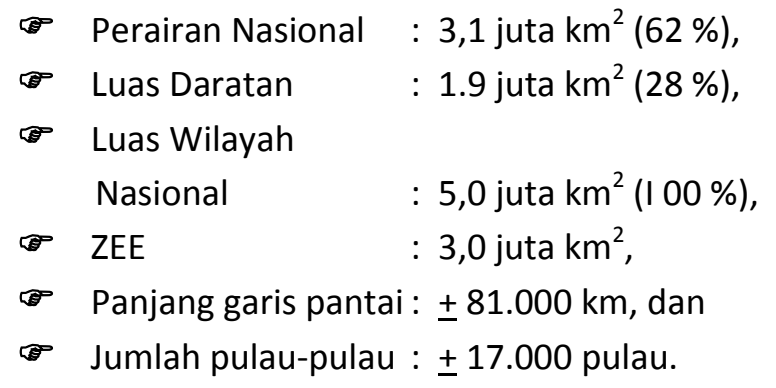

UNCLOS III antara lain terdiri atas aspek-aspek teknik dan beberapa aspek yang terkait dengan disiplin ilmu Geodesi.

\section{ASPEK-ASPEK GEODETIK DALAM HUKUM LAUT}

Aspek-aspek Geodetik dalam Hukum Laut sesuai UNCLOS III termuat dalam bagian 11, bab 2 , pasal $5,6,7,9,10,13,14$, dan 16 ; bagian IV, pasal 47 ; bagian V, pasal 75.

Berdasarkan pasal-pasal yang termuat dalam UNCLOS III, aspek-aspek Geodetik tersebut adalah (Mira et al, 1992):

Garis dasar (baseline),

Tinggi pasut (pasang surut) rendah (low tide elevation),

$\rightarrow$ Garis air rendah (low water line),

Koordinat geografi (geographic coordinat),

Datum geodesi (geodetic datum),

Peta dan chart (map dan chart).

\section{Pengertian Peta, Chart, dan Geodesi}

Menurut Rais (2000), peta adalah abstraksi bentuk grafik dunia nyata pada selembar kertas, disajikan dalam tanda-tanda (titik, garis, dan luasan), warna-warna, simbol-simbol, dan diskalakan. Peta juga merupakan proyeksi matematik dari dunia nyata ke bidang (dunia maya) yang diskalakan. Adapun chart adalah peta tematik (peta dengan tema tertentu) yang dibuat khusus untuk keperluan navigasi (pelayaran).

Pada umumnya kenampakan permukaan bumi yang digambarkan dalam peta adalah posisi horisontal dan posisi vertikal. Posisi horisontal merujuk pada posisi permukaan referensi horisontal berupa bidang geopotensial yang berimpit dengan permukaan laut rerata tak terganggu yang disebut geoid. Karena parameter geoid cukup rumit, maka dipilih bidang hitung pengganti, yaitu sebuah ellipsoid. Pada bidang pengganti inilah perhitungan koordinat dilakukan (Gambar 1).

Posisi vertikal (tinggi) adalah penyajian pada peta atau chart dalam terminologi garis yang mempunyai kesamaan tinggi atau kedalaman, umumnya berupa garis kontur atau isobath. Referensi tinggi atau ketinggian nol tanah umumnya adalah permukaan laut rerata. Pada chart permukaan air terendah umumnya dipakai sebagai nilai nol.

Dikaitkan dengan peta, proyeksi matematik yang dimaksud di atas adalah proyeksi dari ellipsoid ke bidang gambar. Penentuan posisi, proyeksi peta, dan penentuan datum geodesi merupakan sebagian lingkup ilmu Geodesi.

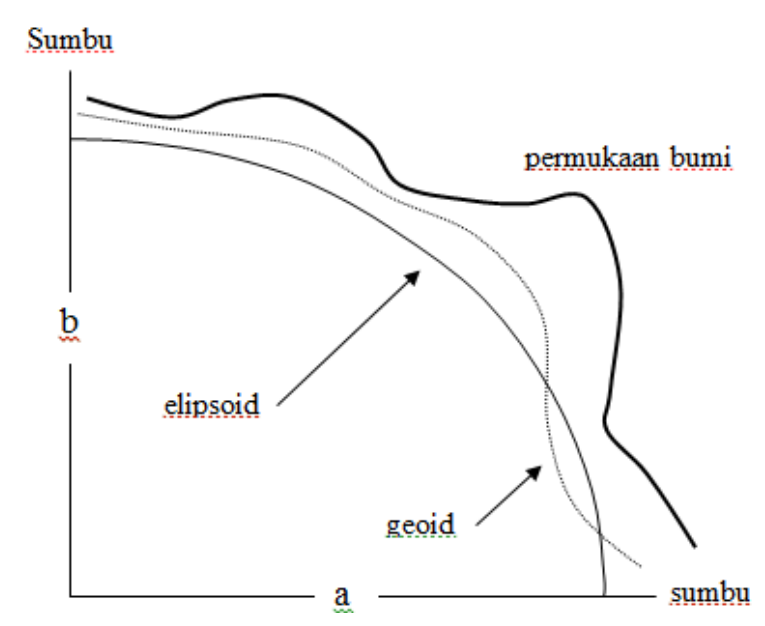

Gambar 1. Potongan Bumi yang Memperlihatkan Hubungan antara Geoid, Elipsoid, dan Permukaan Bumi

\section{Keterangan}

a : setengan sumbu panjang elipsoid, dan

b : setengah sumbu pendek elipsoid. 


\section{Penentuan Tinggi Pasut Rendah (low tide elevation)}

Tinggi pasut rendah sangat diperlukan untuk menentukan titik awal dari garis dasar (baseline), baik ke arah 12 mil laut teritorial maupun ke arah 200 mil laut dalam ZEE. Titik-titik dasar ini di lapangan (di pantai) harus ditandai dengan suatu patok yang dikenal sebagai Bench Mark (BM). Prosedur pengukuran tersebut dapat dilihat pada Gambar 2 berikut.

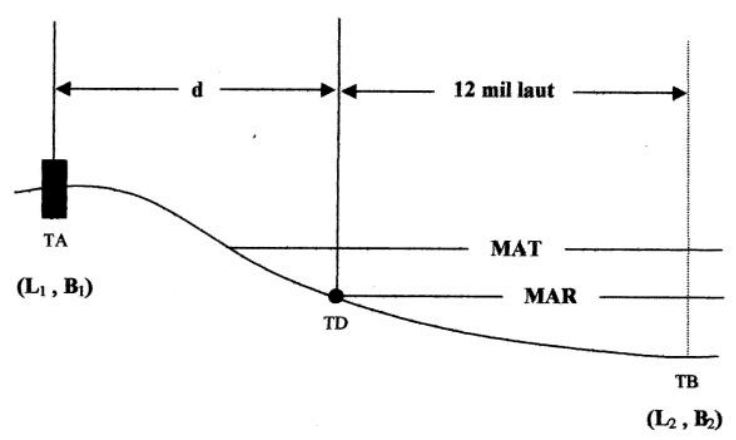

Gambar 2. Pengukuran Tinggi Pasut Rendah (Sumber : Rais, 2001)

Titik pada garis batas di wilayah laut ditentukan dengan menghitung koordinat geografisnya yaitu diukur koordinat titik acuan (misalnya dengan GPS), diukur jarak dan asimut TA ke titik dasar TD di garis pantai pada surut rendah, dan diketahui jarak 12 mil laut dari TD ke titik batas TB.

\section{Keterangan}

TD : titik dasar garis pantai pada surut rendah,

TA : titik acuan,

TB : titik batas di laut,

D : jarak antara TA - TD yang diukur,

MAT : muka air tinggi,

MAR : muka air rendah,

(L1, B1) : lintang dan bujur di titik acuan, dan

(L2, B2) : lintang dan bujur di titik batas di laut.

\section{Garis Air Rendah (low water line)}

Garis air rendah adalah perpotongan bidang saat air rendah dengan pantai (IHO, 1993). Pada kenyataan di lapangan garis ini ditarik antar titik dasar garis pantai pada surut rendah. Garis ini merupakan acuan untuk menghitung lebar laut teritorial maupun untuk menghitung ZEE.

Guna pengukuran secara efisien tidak semua tekuk diberi tanda, tetapi cukup dipilih titik-titik yang menonjol saja (periksa Gambar 3).

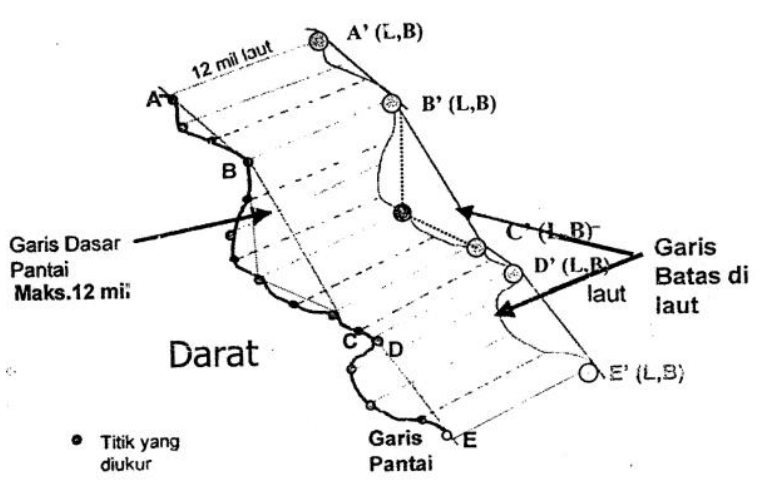

Gambar 3. Pengukuran Batas di Laut dari Garis Pantai dan Garis Dasar (Sumber : Rais, 2001)

\section{Garis Dasar (baseline)}

Garis dasar umumnya lurus dan bilamana tidak mungkin ditarik garis dasar biasa, maka ditarik garis dasar normal (normal baseline), yaitu garis yang ditarik tegak lurus pada titik dasar pada garis pantai pada saat surut rendah (Rais, 2001). Garis dasar normal umumnya diterapkan pada pulau-pulau kecil, sehingga garis batas membentuk lingkaran dengan radius $X$ mil laut (periksa Gambar 4 dan 5). 


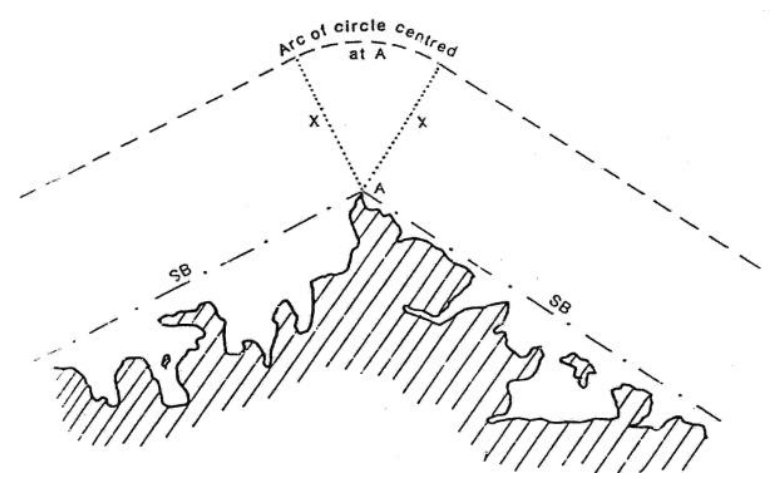

Gambar 4. Batas Berdasarkan Garis Normal (Sumber : IHO, 1993)

\section{Keterangan}

: garis air rendah,

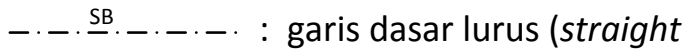
baseline),

: batas kelaut pada X mil laut dari garis dasar,

A

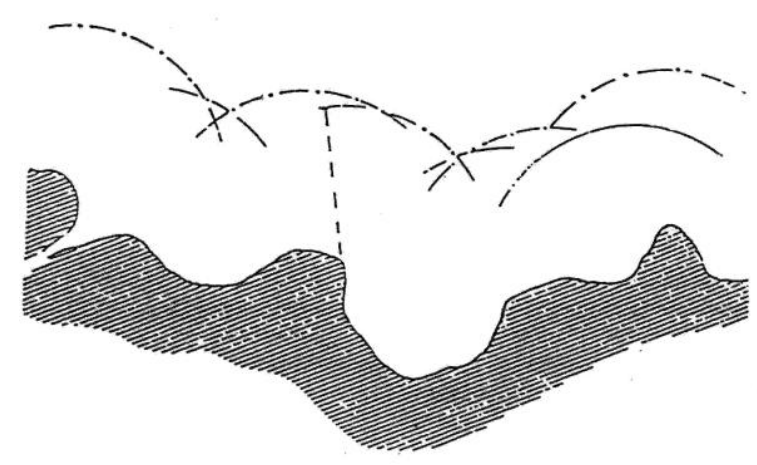

Gambar 5. Kombinasi Garis Dasar dan Garis Dasar Normal (Sumber : IHO, 1993)

\section{Keterangan:}

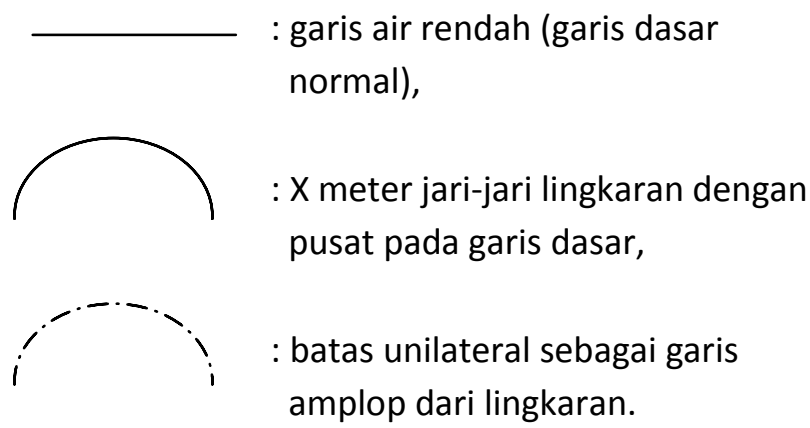

\section{Koordinat Geografi dan Datum Geodesi}

Koordinat geografi adalah parameter sudut lintang dan bujur yang mendefinisikan posisi titik pada permukaan bumi (IHO, 1993). Posisi titik dipermukaan bumi (lintang dan bujur) ditentukan berdasar apa yang disebut datum geodesi, yaitu suatu bidang referensi geodetik dalam hubungannya dengan geoid dan sistem referensi astronomi.

Sesuai dengan UNCLOS III (IHO, 1993), titik-titik dasar garis pantai, titik-titik dasar batas teritorial dan titik-titik dasar ZEE harus dilaporkan koordinatnya. Koordinat-koordinat tersebut berupa daftar koordinat lintang (L) dan bujur (B) dalam sistem tertentu untuk Indonesia berdasarkan referensi Speroid Nasional Indonesia (SNI) yang merupakan adopsi dari GRS $1967 . \quad$ Penentuan referensi ini sudah barang tentu berdasarkan datum Indonesia, begitu pula peta dan chart yang memuat wilayah Indonesia dengan laut teritorial dan ZEE dibuat berdasarkan sistem referensi dan sistem proyeksi yang berlaku di Indonesia. Untuk peta lingkungan laut Bakosurtanal sudah menerbitkan Peta Lingkungan Laut Indonesia yang memuat batas laut teritorial dan ZEE. 


\section{HASIL DAN PEMBAHASAN}

Masalah yang umum terjadi dalam aspekaspek geodetik dalam hukum laut intemasional adalah ketidaksamaan acuan. Dapat disebutkan disini antara lain:

Ketidaksamaan elipsoid referensi yang
digunakan,
$\begin{aligned} & \text { Ketidaksamaan datum geodesi yang } \\ & \text { digunakan, dan }\end{aligned}$
$\begin{aligned} & \text { Ketidaksamaan sistem proyeksi peta yang } \\ & \text { digunakan. }\end{aligned}$

Di samping masalah tersebut di atas, masih ada masalah lain yaitu pada penentuan air surut rendah. Sebagaimana diketahui permukaan laut tidak sama di beberapa tempat di permukaaan bumi. Banyak faktor yang mempengaruhi, antara lain: arus, gelombang, dan angin. Dalam jangka panjang diperlukan suatu datum global yang dapat disepakati di seluruh dunia. Secara terbatas sebenarnya ini sudah dilakukan dengan adanya GPS yang menggunakan referensi WGS 84. Begitu juga untuk referensi tinggi, di masa depan perlu dipertimbangkan dan dilakukan penelitian penggunaan geoid untuk maksud tersebut.

Untuk waktu sekarang yang diperlukan adalah suatu perangkat lunak yang bisa mentransformasi datum maupun transformasi koordinat yang bisa menjembatani ketidaksamaan-ketidaksamaan di atas.

Khusus untuk Indonesia masih ada masalah, yaitu daftar koordinat yang dimaksud UNCLOS III. Memang Indonesia sudah melaporkan daftar koordinat, namun perlu diketahui sebagian koordinat-koordinat tersebut masih dihitung di atas peta, bukan hasil pengukuran langsung sebagaimana yang diilustrasikan pada Gambar 2, 3,
4, dan 5. Begitu juga peta-peta yang memuat batas teritorial dan ZEE hanya ditentukan di atas peta, bukan hasil pengukuran langsung di lapangan.

\section{PENUTUP}

\section{Simpulan}

IImu Geodesi mempunyai peran yang signifikan dalam hukum laut khususnya dalam penentuan garis dasar, titik dasar kaitannya dengan batas jurisdiksi nasional selebar 12 mil laut dan hak pengelolaan sumber daya pada Zona Ekonomi Eksklusif (ZEE) selebar 200 mil laut. Untuk itu diperlukan suatu perangkat lunak yang bisa mentransformasi datum maupun transformasi koordinat yang bisa menjembatani ketidaksamaanketidaksamaan, baik sistem koordinat maupun datum geodesi.

\section{Saran}

Untuk Indonesia, tugas yang harus segera dikerjakan adalah pengukuran titik-titik dasar langsung di lapangan. Saat ini kendalanya mungkin hanya biaya, karena teknologi untuk itu sudah ada yaitu menggunakan GPS.

\section{DAFTAR PUSTAKA}

IHO (International Hydrographic Organization), 1993. A Mannual on Techical Aspects of the United Nations Convention on Law of the Sea-1982. International Hydrographic Bureau, Monaco.

Kusumaatmadja, M., 1978. Bungai Rampai Hukum Laut. Jakarta: Penerbit Binacipta.

Mira, S., W.N. Sulasdi dan S.B. Hasan, 1992. Problem Areas of the Geodetic Aspect of the Law of the Sea Related to the Indonesian Archipelagic State. Dalam: Geodetic Aspect of the Law of the Sea. Agency for Surveys and Mapping - Indonesian Surveyors Association, June. Denpasar, Indonesia. 
Rais, J. 2000. Slide Kuliah SPL 64I: Inventarisasi dan Evaluasi Sumber Daya Alam. Program Studi SPL IPB. Bogor, Indonesia.

Rais, J. 2001. Slide Kuliah: Pedoman Penggambaran Pengukuran, dan Penetapan Kewenangan Daerah Propinsi dan Kabupaten/Kota di Wilayah Laut. Departemen Kelautan dan Perikanan. Jakarta, Indonesia.

Republik Indonesia, 2008. Undang Undang Republik Indonesia Nomor 43 Tahun 2008 Tentang Batas Negara. Jakarta, Indonesia.

Republik Indonesia, 2011. Undang Undang Republik Indonesia Nomor 4 Tahun 2011 Tentang Informasi Geospasial. Jakarta, Indonesia.

Republik Indonesia, 2014. Undang Undang Republik Indonesia Nomor 23 Tahun 2014 Tentang Pemerintah Daerah. Jakarta, Indonesia. 